\title{
New rhodamine derivative as OFF-ON fluorescent chemosensor for detection of $\mathrm{Cu}^{2+}$
}

\author{
MA Xing ${ }^{1,2}$, LIU Jun $^{1}$, DU YuGuo ${ }^{1,2}$, WEI GuoHua ${ }^{1 *} \&$ WEI DongBin ${ }^{1 *}$ \\ ${ }^{1}$ State Key Laboratory of Environmental Chemistry and Ecotoxicology; Research Center for Eco-Environmental Sciences, Chinese Academy of \\ Sciences, Beijing 100085, China \\ ${ }^{2}$ College of Chemistry and Chemical Engineering, Graduate University of Chinese Academy of Sciences, Beijing 100049, China
}

Received March 20, 2011; accepted June 28, 2011; published online August 5, 2011

\begin{abstract}
A novel fluorescence probe for the detection of $\mathrm{Cu}^{2+}$ has been designed and synthesized, which is based on a ring-opening reaction of spirolactam triggered by $\mathrm{Cu}^{2+}$. This probe exhibits excellent $\mathrm{Cu}^{2+}$ ion selectivity as well as significant color changes visible to the naked eye at the concentration of $0.03 \mathrm{mM}$ (ca. $2.0 \mathrm{mg} / \mathrm{L}$ ), the WHO (World Health Organization) recommended level $(2.0 \mathrm{mg} / \mathrm{L})$ of $\mathrm{Cu}^{2+}$ ions in drinking water. This novel rhodamine-based fluorescence probe can be directly used to detect $\mathrm{Cu}^{2+}$ with satisfactory sensitivity and selectivity in aqueous solution.
\end{abstract}

copper, fluorescent chemosensor, rhodamine, naked-eye detection

\section{Introduction}

Copper is the third-most abundant transition metal in the body [1]. $\mathrm{Cu}^{2+}$ plays a critical role as a catalytic cofactor for a variety of metalloenzymes and transcriptional events [2]. However, under overloading conditions, copper exhibits toxicity in that it causes Alzheimer's and Wilson's diseases probably by its involvement in the production of reactive oxygen species [3, 4]. Therefore, a fast, convenient, and reliable method for $\mathrm{Cu}^{2+}$ detection is required, particularly in drinking water monitoring. Sensors based on the ioninduced changes in fluorescence appear to be particularly attractive because of the simplicity and high detection limit of the fluorescence [5]. Recently, rhodamine derivatives have been utilized as useful fluorophores due to their excellent spectroscopic properties of large molar extinction coefficient and high fluorescence quantum yield. The fluorescent chemosensors based on the rhodamine derivatives have been applied as $\mathrm{Pb}^{2+}$ sensor [6], $\mathrm{Hg}^{2+}$ sensor [7, 8], $\mathrm{Fe}^{3+}$ sensor [9], $\mathrm{Cr}^{3+}$ sensor [10], $\mathrm{Ag}^{+}$sensor [11] and $\mathrm{Cu}^{2+}$ sen-

*Corresponding author (email: wgh@ rcees.ac.cn; weidb@rcees.ac.cn) sor [12-16]. Rhodamine derivatives are nonfluorescent and colorless, whereas addition of targeted metal cation leading to ring-opening of the corresponding spirolactam gives rise to strong fluorescence emission and a pink color. Based on the understanding of the sensing mechanism of rhodamine-based molecular sensors, herein, we disclose a design and synthesis of a new rhodamine-based chemosensor $\mathbf{1}$, with rhodamine $\mathrm{B}$ as the fluorophore and 4- $\mathrm{N}, \mathrm{N}$-bis-(2acetoxyethyl) aminobenzaldehyde, a $\mathrm{Cu}^{2+}$-selective ligand, as the ion acceptor. Chemosensor $\mathbf{1}$ shows a selective, sensitive fluorescence enhancement response to $\mathrm{Cu}^{2+}$ in a mixed aqueous environment. The improvement in the color response, rapid and accurate recognition of $\mathrm{Cu}^{2+}$ with naked-eye will make this approach a very promising one for the detection of $\mathrm{Cu}^{2+}$ in water media.

\section{Experimental}

\subsection{General experimental}

Fluorescence spectra were obtained by using a Hitachi F-7000 fluorescence spectrometer equipped with an xenon 
lamp, $1.0 \mathrm{~cm}$ quartz cells, and slits of 1.0/1.0 nm. The ${ }^{1} \mathrm{H}$ and ${ }^{13} \mathrm{C}$ NMR spectra were recorded on ARX 400 spectrometers for solutions in $\mathrm{CDCl}_{3}$ or $\mathrm{CD}_{3} \mathrm{OD}$. Chemical shifts are given in ppm downfield from internal $\mathrm{Me}_{4} \mathrm{Si}$. High-resolution mass spectrometry was conducted in a positive mode using ESI-source. Thin layer chromatography (TLC) was performed on silica gel $\mathrm{HF}_{254}$ with detection by charring with $30 \%(v / v) \mathrm{H}_{2} \mathrm{SO}_{4}$ in $\mathrm{MeOH}$ or in some cases by a UV detector.

\subsection{Synthesis}

Rhodamine $\mathrm{B}$ and 4- $N, N$-bis-(2-hydroxyethyl)aminobenzaldehyde were purchased from Alfa Aesar. All chemicals were of reagent grade and used without further purification. Ultrapure water with a millipore purification system (Milli-Q water) was used throughout the analytical experiments.

Compound 1: Rhodamine hydrazine (2, $0.46 \mathrm{~g}, 1.0 \mathrm{mmol})$ was dissolved in absolute ethanol $(20 \mathrm{~mL})$. An excess of 4- $N, N$-bis-(2-acetoxyethyl)aminobenzaldehyde $(3,1.17 \mathrm{~g}$, $4.0 \mathrm{mmol}$ ) was added and the mixture was heated at reflux for $4 \mathrm{~h}$. The precipitate produced was filtered and washed with cold ethanol. The crude product was purified by recrystallization from ethanol to afford $\mathbf{1}$ as yellow solid $(0.58$ g, 79\%). ${ }^{1} \mathrm{H}$ NMR (400 MHz, $\mathrm{CDCl}_{3}$ ), $\delta$ (TMS, ppm): 1.15 $(\mathrm{t}, 12 \mathrm{H}, J=16 \mathrm{~Hz}), 2.02(\mathrm{~s}, 6 \mathrm{H}), 3.31(\mathrm{~m}, 8 \mathrm{H}), 3.68(\mathrm{t}, 4 \mathrm{H}$, $J=6.2 \mathrm{~Hz}), 4.21(\mathrm{t}, 4 \mathrm{H}, J=6.2 \mathrm{~Hz}), 6.26(\mathrm{~d}, 2 \mathrm{H}, J=8.1$ $\mathrm{Hz}), 6.45(\mathrm{~m}, 4 \mathrm{H}), 6.65(\mathrm{~d}, 2 \mathrm{H}, J=8.6 \mathrm{~Hz}), 7.07(\mathrm{~d}, 1 \mathrm{H}, J=$ $8.1 \mathrm{~Hz}), 7.45(\mathrm{~m}, 1 \mathrm{H}), 7.51(\mathrm{t}, 2 \mathrm{H}, J=16 \mathrm{~Hz}), 7.70(\mathrm{~d}, 2 \mathrm{H}$, $J=8.8 \mathrm{~Hz}), 8.01(\mathrm{~d}, \quad 1 \mathrm{H}, J=8.1 \mathrm{~Hz}) \cdot{ }^{13} \mathrm{CNMR}\left(\mathrm{CDCl}_{3}\right.$, $100 \mathrm{MHz}) \delta$ (TMS, ppm): 12.5 (4C), 20.5 (2C), 44.3 (4C), 55.5 (2C), 61.6 (2C), 67.2, 98.3 (2C), 103.5, 108.1, 111.7, $112.5,114.8$ (2C), 123.8, 126.7, 127.4, 128.3 (2C), 128.6, $129.1,129.5,132.5,134.6,141.2,146.5,149.2$ (2C), 151.9, 152.6, 152.9, 165.9, 170.1, 170.3. ESI(+)-HRMS (m/z): [M $+\mathrm{H}]^{+}$calcd. for $\mathrm{C}_{43} \mathrm{H}_{50} \mathrm{~N}_{5} \mathrm{O}_{6}: 732.3761$, found 732.3768 .

\subsection{Sample preparation}

Stock solution of probe $\mathbf{1}(1.0 \mathrm{mM})$ was prepared in a co-solvent of $\mathrm{CH}_{3} \mathrm{CN}$ and HEPES (4-(2-hydroxyethyl)-1piperazine-ethanesulfonic acid) buffer (20.0 mM, pH 7.4, $1 / 1, V / V)$, and the stock solutions of $\mathrm{Cu}^{2+}$ and other cation ions $(10.0 \mathrm{mM})$ were prepared by dissolving corresponding chloride salts in HEPES buffer (20.0 mM, pH 7.4).

\subsection{Fluorescence analysis}

$1.00 \mathrm{~mL}$ of probe $1(1.0 \mathrm{mM})$ was blended with $0.10 \mathrm{~mL}$ of $\mathrm{Cu}^{2+}$ solution $(10.0 \mathrm{mM})$ in HEPES buffer $(20.0 \mathrm{mM}, \mathrm{pH}$ 7.4 ) in a $10 \mathrm{~mL}$ colorimetric tube. After addition of 20.0 $\mathrm{mM}$ of HEPES buffer to bring the volume up to $10.00 \mathrm{~mL}$, the mixture was equilibrated for $10 \mathrm{~min}$ and then the fluorescence intensity was recorded at $\lambda_{\mathrm{ex}} / \lambda_{\mathrm{em}}=550 / 590 \mathrm{~nm}$ alongside a reagent blank. The excitation and emission slits were both set to $1.0 / 1.0 \mathrm{~nm}$.

\section{Results and discussion}

\subsection{Designation and synthesis of probe 1}

Rhodamine hydrazide 2 was synthesized according to the literature procedure [17]. Chemosensor 1 was synthesized by treating rhodamine hydrazide 2 with 4- $N, N$-bis-2-acetoxyethyl) aminobenzaldehyde 3 [18] with a high yield (Scheme 1). The molecular structure was confirmed by NMR and MS.

\subsection{Selectivity of probe 1}

Probe 1 can dissolve in a co-solvent of $\mathrm{CH}_{3} \mathrm{CN}$ and HEPES solution $(20.0 \mathrm{mM}$, pH 7.4, 1/1, V/V), and the solution itself is non-fluorescent and colorless. A variation of $\mathrm{pH}$ from 5.0 to 10.0 does not cause significant changes in fluorescence intensity, which implies that probe $\mathbf{1}$ itself is relatively stable and of potential use in aqueous media. When $\mathrm{Cu}^{2+}$ is added into the solution, it can chelate with $4-N, N$-bis-(2acetoxyethyl) aminobenzaldehyde, induce ring-opening at $\mathrm{C}-\mathrm{N}$ bond in spirolactam and generate a rhodamine-type intermediate with a strong fluorescence signal and a blue purple color visible to the naked eye (Figure 1). The three-dimensional excitation emission matrix (3D-EEM) fluorescence spectroscopic analysis on probe 1 solution and mixture solution of probe $\mathbf{1}$ and $\mathrm{Cu}^{2+}$ was performed at

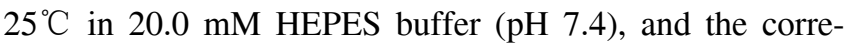
sponding spectra are shown in Figure 2. It can be seen that there was no significant fluorescence signal for probe $\mathbf{1}$ solution, while a strong fluorescence peak rapidly appeared after adding $\mathrm{Cu}^{2+}$ to the probe 1 solution (Figure 3 ). The maximum excitation wavelength of test solution was at 550 $\mathrm{nm}$, and the maximum emission wavelength at $590 \mathrm{~nm}$. The selectivity of probe $\mathbf{1}$ for $\mathrm{Cu}^{2+}$ against other individual cati-

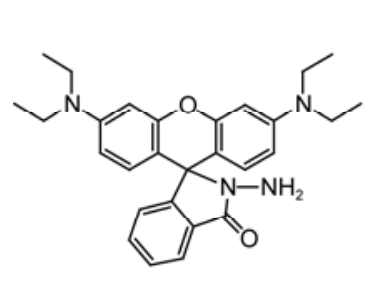

2

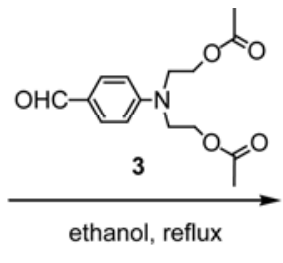

ethanol, reflux

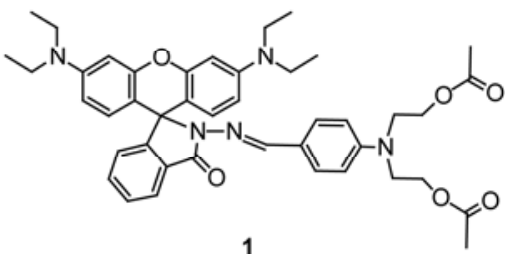

Scheme 1 Synthesis of rhodamine-based chemosensor 1. 


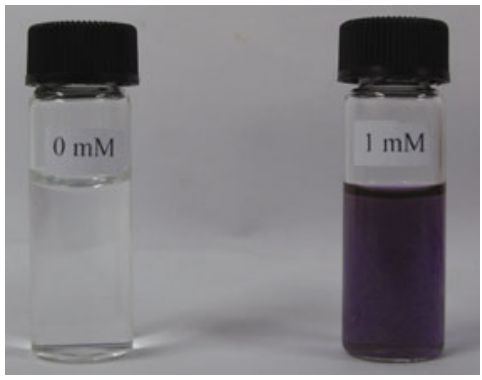

Figure 1 "Naked-eye" color changes of probe $1(0.10 \mathrm{mM}$ in $20.0 \mathrm{mM}$ of HEPES buffer system, pH 7.4) before and after adding $\mathrm{Cu}^{2+}(1.0 \mathrm{mM})$.

on ions was explored by adding probe $1(0.10 \mathrm{mM})$ to each aqueous solution of $\mathrm{Ag}^{+}, \mathrm{Ca}^{2+}, \mathrm{Cu}^{2+}, \mathrm{Ni}^{2+}, \mathrm{Mg}^{2+}, \mathrm{Fe}^{2+}, \mathrm{Hg}^{2+}$, $\mathrm{Pb}^{2+}, \mathrm{Co}^{2+}, \mathrm{Mn}^{2+}, \mathrm{Cd}^{2+}$, and $\mathrm{Zn}^{2+}(1.0 \mathrm{mM})$, respectively. As shown in Figure 4, only $\mathrm{Cu}^{2+}$ induced a significant fluorescence signal, and appeared a blue purple color from the colorless test solution (probe $\mathbf{1}$ as blank). Addition of other cation ions up to a concentration as high as $1.0 \mathrm{mM}$ caused
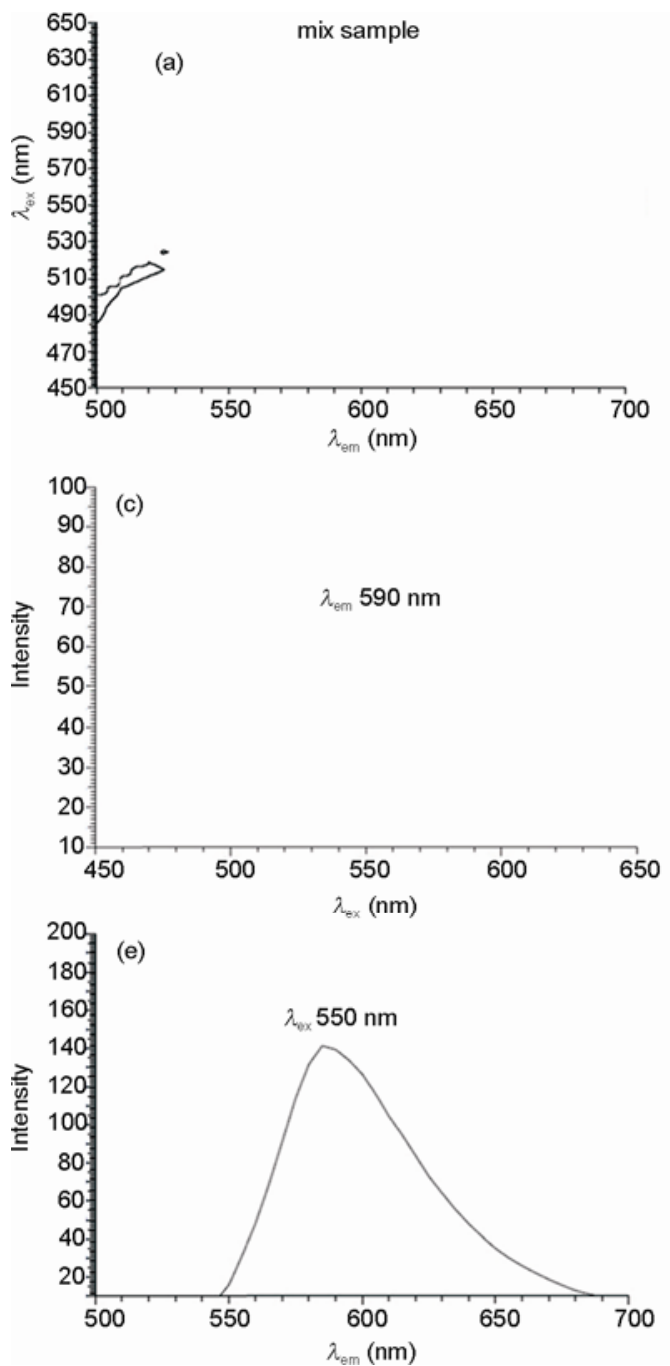

no detectable increase of both fluorescence signal and color changes to the naked eye.

\subsection{Sensitivity of probe 1}

Figure 5 shows the emission fluorescence spectra of probe 1 on addition of $\mathrm{Cu}^{2+}$ with various concentrations. When excited at $550 \mathrm{~nm}$, the emission fluorescence intensity of probe 1 at $590 \mathrm{~nm}$ increased more than 26-fold on increasing the concentration of $\mathrm{Cu}^{2+}$ from 0 to $0.10 \mathrm{mM}$. A satisfactory linear relationship between fluorescence intensity and $\mathrm{Cu}^{2+}$ concentration was observed with the correlation coefficient as high as 0.9936. Similarly, as shown in Figure 6, the UV absorption spectra of probe $\mathbf{1}$ had a significant change as addition of $\mathrm{Cu}^{2+}$, and the absorbance at $705 \mathrm{~nm}$ enhanced from 0.003 to 0.200 on increasing concentration of $\mathrm{Cu}^{2+}$ from 0 to $0.10 \mathrm{mM}$.

In order to check the effect of ion strength on the fluo-
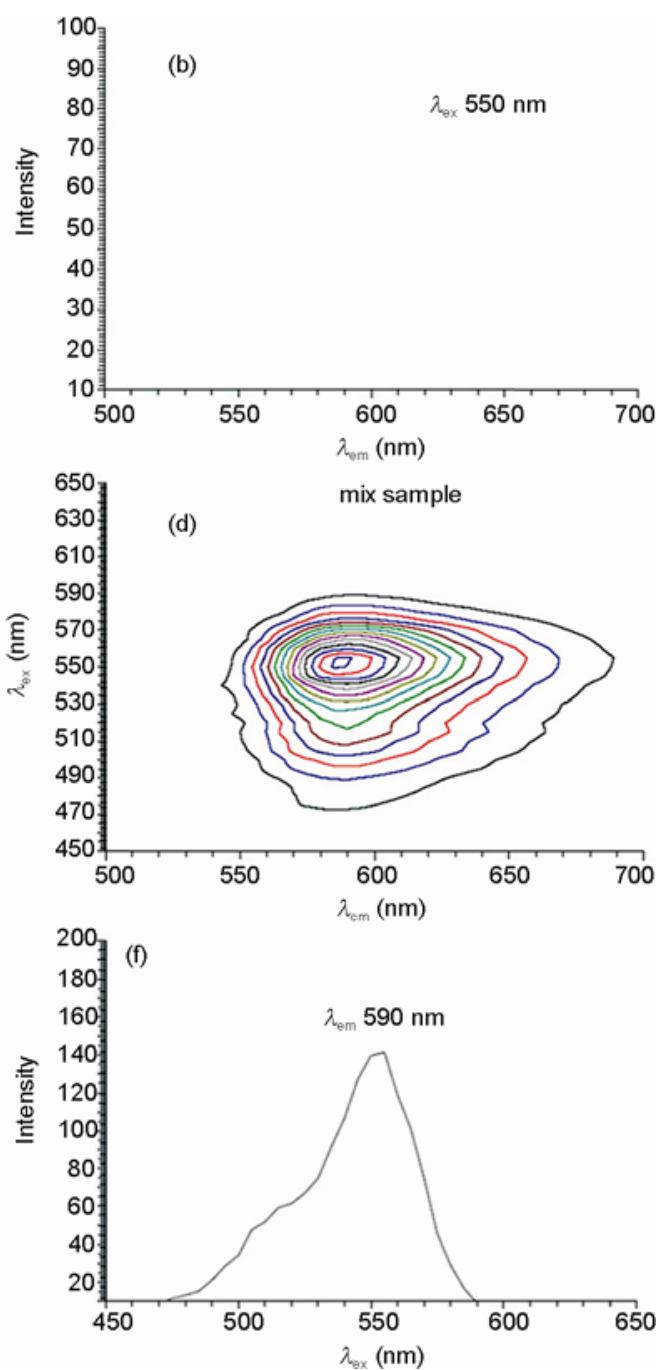

Figure 2 Fluorescence characteristics of probe $\mathbf{1}(0.10 \mathrm{mM})$ and mixture of probe $\mathbf{1}(0.10 \mathrm{mM})$ and $\mathrm{Cu}^{2+}(0.05 \mathrm{mM})$ in HEPES buffer system $(20.0 \mathrm{mM}$, pH 7.4). (a) 3D-EEM spectra of probe $\mathbf{1}$ in HEPES buffer system; (b) emission scanning spectra of probe $\mathbf{1}$ when fixing excitation wavelength at $550 \mathrm{~nm}$; (c) excitation scanning spectra of probe $\mathbf{1}$ when fixing emission wavelength at $590 \mathrm{~nm}$; (d) $3 \mathrm{D}-\mathrm{EEM}$ spectra of $\mathrm{Cu}^{2+}$ and probe 1; (e) emission scanning spectra of $\mathrm{Cu}^{2+}$ and probe 1 when fixing excitation wavelength at $550 \mathrm{~nm}$, (f) excitation scanning spectra of $\mathrm{Cu}^{2+}$ and probe $\mathbf{1}$ when fixing emission wavelength at $590 \mathrm{~nm}$. 


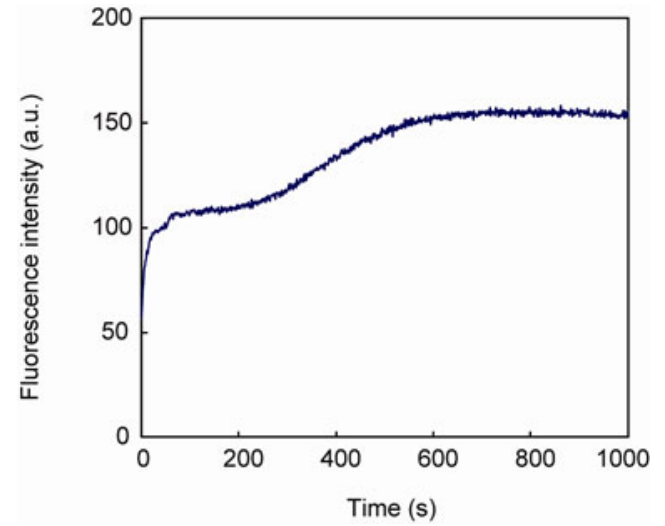

Figure 3 Time-dependant fluorescence scanning on the mixture of probe $1(0.10 \mathrm{mM})$ and $\mathrm{Cu}^{2+}(0.05 \mathrm{mM})$ in HEPES buffer system $(20.0 \mathrm{mM}, \mathrm{pH}$ 7.4). The excitation wavelength was set at $550 \mathrm{~nm}$, and the emission wavelength at $590 \mathrm{~nm}$, with slit widths of $1.0 \mathrm{~nm}$.
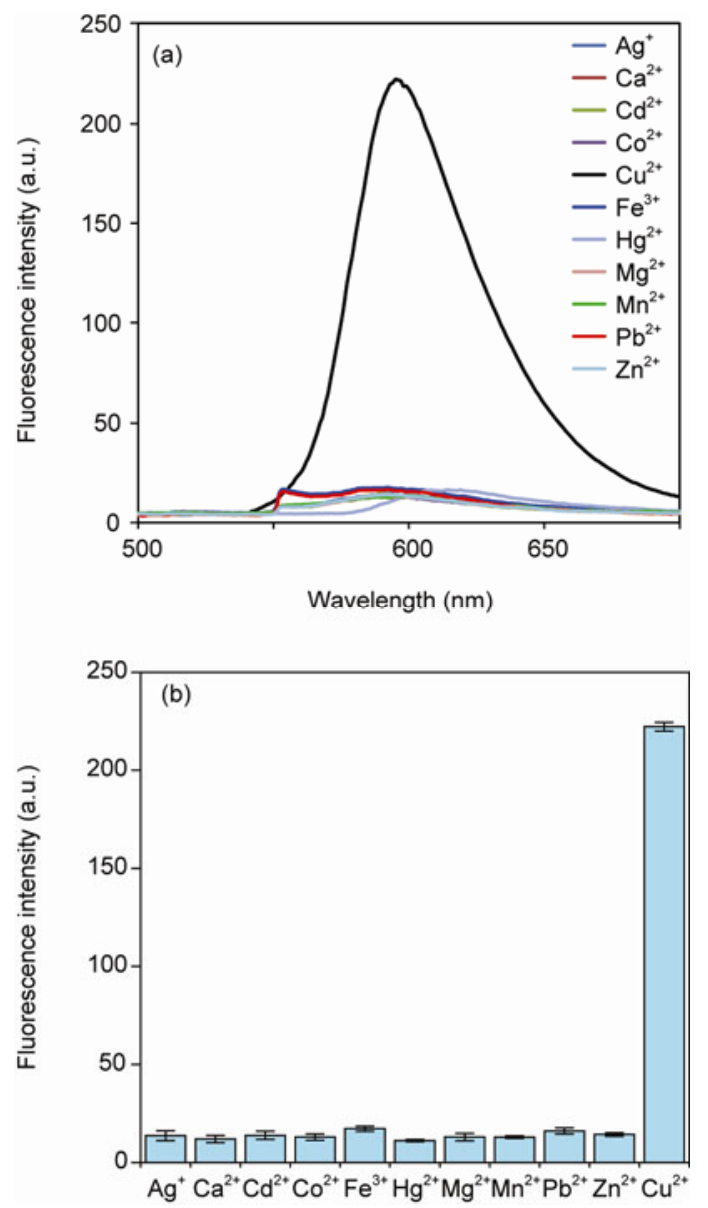

Figure 4 Cation selectivity of probe 1 . Each cation $\left(\mathrm{Ag}^{+}, \mathrm{Ca}^{2+}, \mathrm{Cu}^{2+}, \mathrm{Ni}^{2+}\right.$, $\mathrm{Mg}^{2+}, \mathrm{Fe}^{2+}, \mathrm{Hg}^{2+}, \mathrm{Pb}^{2+}, \mathrm{Co}^{2+}, \mathrm{Mn}^{2+}, \mathrm{Cd}^{2+}$, and $\mathrm{Zn}^{2+}$ ) was added at a concentration of $1.0 \mathrm{mM}$ to a $20.0 \mathrm{mM}$ HEPES buffer system (pH 7.4) of probe 1 $(0.1 \mathrm{mM})$. (a) Fluorescence spectra of cation ions with probe 1; (b) fluorescence intensity of each cation ion and probe $\mathbf{1}$, the excitation wavelength was set at $550 \mathrm{~nm}$, and the emission wavelength at $590 \mathrm{~nm}$, with slit widths of $1.0 \mathrm{~nm}$.

rescence characteristics of probe $\mathbf{1}$, a solution of $1.0 \mathrm{M}$ $\mathrm{NaNO}_{3}$ was added to the reaction system of $\mathrm{Cu}^{2+}(1.0 \mathrm{mM})$
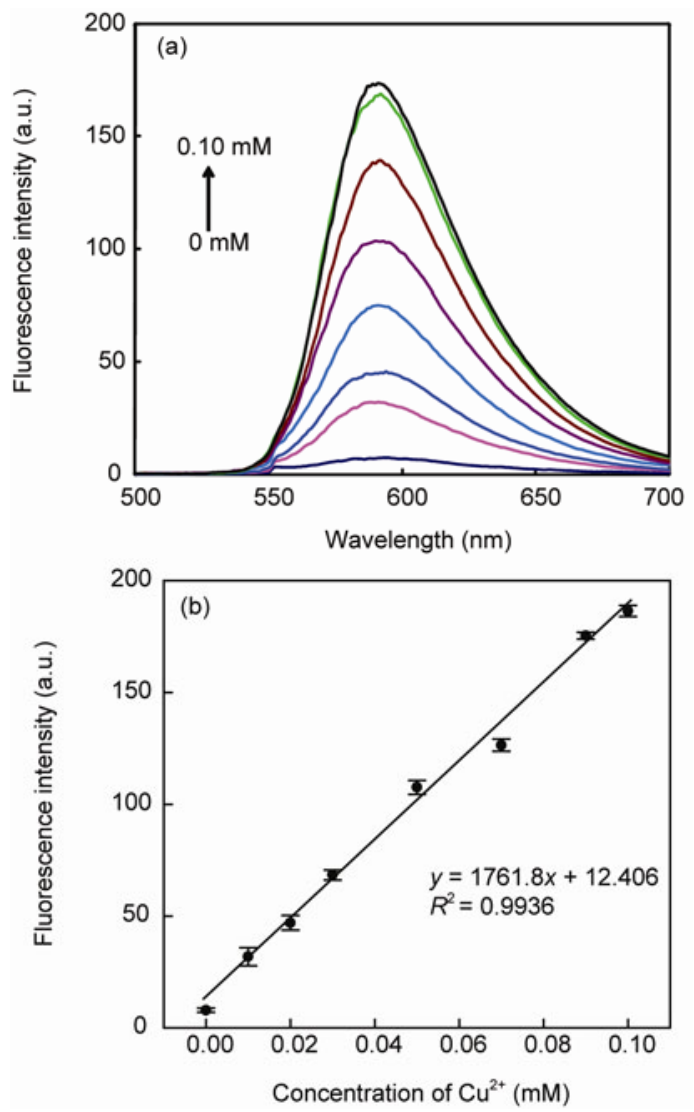

Figure 5 (a) Fluorescence emission changes of probe $1(0.10 \mathrm{mM})$ recorded $10 \mathrm{~min}$ after reaction with various concentrations of $\mathrm{Cu}^{2+}(0-0.10$ $\mathrm{mM})$ in $20.0 \mathrm{mM}$ HEPES buffer system $\left(\mathrm{pH} \mathrm{7.4)}\right.$ at $25{ }^{\circ} \mathrm{C}$. Excitation wavelength was at $550 \mathrm{~nm}$, with silt widths of $1.0 \mathrm{~nm}$; (b) dependence of fluorescence intensity at $590 \mathrm{~nm}$ with respect to concentrations of $\mathrm{Cu}^{2+}$ ions $(0-0.10 \mathrm{mM})$ in $20.0 \mathrm{mM}$ HEPES buffer system $\left(\mathrm{pH} \mathrm{7.4)}\right.$ at $25{ }^{\circ} \mathrm{C}$. Excitation wavelength was at $550 \mathrm{~nm}$, with silt widths of $1.0 \mathrm{~nm}$.

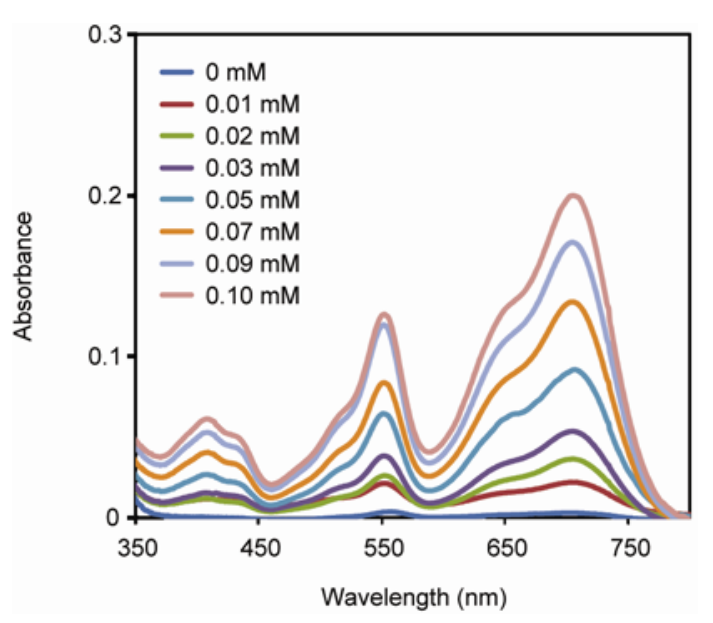

Figure 6 UV absorption changes of probe $1(0.10 \mathrm{mM})$ recorded $10 \mathrm{~min}$ after reaction with various concentrations of $\mathrm{Cu}^{2+}(0-0.10 \mathrm{mM})$ in 20.0 mM HEPES buffer system (pH 7.4) at $25^{\circ} \mathrm{C}$.

and probe $1(0.1 \mathrm{mM})$ in $20.0 \mathrm{mM}$ HEPES buffer $(\mathrm{pH} 7.4)$ at $25{ }^{\circ} \mathrm{C}$. It was found that the addition of $\mathrm{NaNO}_{3}$ did not change the fluorescence intensity at all, the mean fluorescence intensity of 4 runs was 239.53 and 244.12 a.u. for 
system with and without adding of $\mathrm{NaNO}_{3}$, respectively. Furthermore, the detection limit of $\mathrm{Cu}^{2+}$ in HEPES buffer with the synthesized probe $\mathbf{1}$ was determined using both $\mathrm{S} / \mathrm{N}$ test method and serial dilution method. It was found that the detection limit was as low as $0.006 \mathrm{mM}(0.40$ $\mathrm{mg} / \mathrm{L})$, the relative standard deviation of eleven runs was $6.5 \%$. The detection limit $(0.40 \mathrm{mg} / \mathrm{L})$ of probe 1 to $\mathrm{Cu}^{2+}$ is significantly lower than the recommended water quality standard of $\mathrm{Cu}^{2+}(2.0 \mathrm{mg} / \mathrm{L})$ for drinking water by WHO (World Health Organization) [19], EU (European Union) [20], and Australia [21]. The present result implies that probe 1 can be simply, rapidly, and satisfactorily used to detect the concentration of $\mathrm{Cu}^{2+}$. Apparently, under naked-eye conditions, the blue purple color of the solution is of correlation with the concentration of probe $\mathbf{1}$ and $\mathrm{Cu}^{2+}$. Figure 7 shows the color variation of probe 1 solution in terms of different $\mathrm{Cu}^{2+}$ concentration. It can be seen that the color changes could be exclusively confirmed with naked-eye when the $\mathrm{Cu}^{2+}$ concentration increased to $0.03 \mathrm{mM}$ (ca. $2.0 \mathrm{mg} / \mathrm{L}$ ), the recommended standard value for $\mathrm{Cu}^{2+}$ in drinking water by WHO, EU and Australia. This observation suggested that probe $\mathbf{1}$ could be used conveniently to check if the $\mathrm{Cu}^{2+}$ concentration of the sample meets the drinking water quality requirement with naked-eye.

\section{Conclusion}

In summary, we have designed, synthesized, and investigated the properties of a new fluorescence probe $\mathbf{1}$ for $\mathrm{Cu}^{2+}$ detection based on the ring-opening of spirolactam. Fluorescence probe 1 exhibited an excellent $\mathrm{Cu}^{2+}$ selectivity over other cation ions, as well as a satisfactory detection limit at $0.40 \mathrm{mg} / \mathrm{L}$. More importantly, the probe displayed significant naked-eye color changes at $2.0 \mathrm{mg} / \mathrm{L}$, the standard value that $\mathrm{WHO}$ recommended for $\mathrm{Cu}^{2+}$ ion in drinking water, providing a rapid, convenient and cheap kit to check if $\mathrm{Cu}^{2+}$ concentration in water sample exceeds the quality standard for domestic consumers.

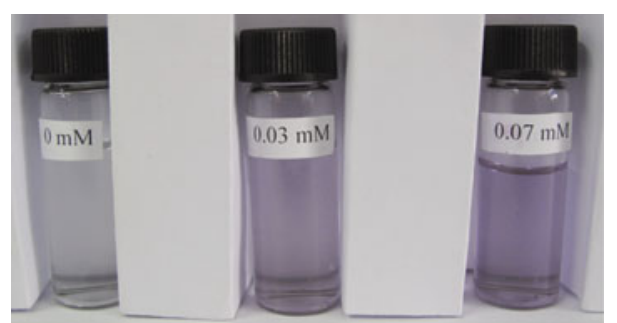

Figure 7 "Naked-eye" color changes of probe $\mathbf{1}(0.10 \mathrm{mM}$ in $20.0 \mathrm{mM}$ HEPES buffer, $\mathrm{pH}$ 7.4) upon addition of different concentration of $\mathrm{Cu}^{2+}$ (From left: 0, 0.03 and $0.07 \mathrm{mM}$ ).

This work was supported in partial by the National Natural Science Foundation of China (20921063 \& 20877090) and the National High Technology Research and Development Program (863 Program, 2007AA06A407).
1 Gaggelli E, Kozlowski H, Valensin D, Valensin G. Copper homeostasis and neurodegerative disorders (Alzheimer's, Prion, and Parkinson's Diseases and Amyotrophic Lateral Sclerosis). Chem Rev, 2006, 106: 1995-2044

$2 \mathrm{Hu} \mathrm{S}$, Furst P, Hamer D. The DNA and $\mathrm{Cu}$ binding functions of ACE1 are interdigitated within a single domain. New Biol, 1990, 2: 544-555

3 Muthaup G, Schlicksupp A, Hess L, Beher D, Ruppert T, Masters CL, Beyreuther K. The amyloid precursor protein of Alzheimer's disease in the reduction of copper(II) to copper(I). Science, 1996, 271: 1406-1409

4 Løvstad R A. A kinetic study on the distribution of $\mathrm{Cu}(\mathrm{II})$-ions between albumin and transferring. BioMetals, 2004, 17: 111-113

5 Martínez-Máñez R, Sancanón F. Fluorogenic and chromogenic chemosensors and reagents for anions. Chem Rev, 2003, 103: 4419-4476 and references cited therein

6 Kwon JY, Jang YJ, Lee YJ, Kim KM, Seo MS, Nam WW, Yoon JY. A highly selective fluorescent chemosensor for $\mathrm{Pb}^{2+}$. J Am Chem Soc, 2005, 127: 10107-10111 and references cited therein

7 Ko SK, Yang YK, Tae J, Shin I. In Vivo monitoring of mercury ions using a rhodamine-based molecular probe. J Am Chem Soc, 2006, 128: $14150-14155$

8 Zhou Y, You XY, Fang Y, Li JY, Liu K, Yao C. A thiophen-thiooxorhodamine conjugate fluorescent probe for detecting mercury in aqueous media and living cells. Org Biomol Chem, 2010, 8: 48194822 and references cited therein

9 Xiang Y, Tong A. A new rhodamine-based chemosensor exhibiting selective Fe(III)-amplified fluorescence. Org Lett, 2006, 8: 1549-1552

10 Mao J, Wang L, Dou W, Tang XL, Yan Y, Liu WS. Tuning the selectivity of two chemosensors to Fe(III) and Cr(III). Org Lett, 2007, 9: 4567-4570

11 Chatterjee A, Santra M, Won N, Kim S, Kim JK, Kim SB, Ahn KH. Selective fluorogenic and chromogenic probe for detection of silver ions and silver nanoparticles in aqueous media. J Am Chem Soc, 2009, 131: 2040-2041

12 Zhang X, Shiraishi Y, Hirai T. Cu(II)-selective green fluorescence of a rhodamine-diacetic acid conjugate. Org Lett, 2007, 9: 5039-5042

13 Yu FB, Zhang WS, Li P, Xing YL, Tong LL, Ma JP, Tang B. $\mathrm{Cu}^{2+}$ selective naked-eye and fluorescent probe: its crystal structure and application in bioimaging. Analyst, 2009, 134: 1826-1833 and references cited therein

14 Yu CW, Zhang J, Wang R, Chen LX. Highly sensitive and selective colorimetric and off-on fluorescent probe for $\mathrm{Cu}^{2+}$ based on rhodamine derivative. Org Biomol Chem, 2010, 8: 5277-5279 and references cited therein

15 Zhou Y, Wang F, Kim YM, Kim SJ, Yoon JY. $\mathrm{Cu}^{2+}$-selective ratiometric and "Off-On" sensor based on the rhodamine derivative bearing pyrene group. Org Lett, 2009, 11: 4442-4445 and references cited therein

16 Huang L, Wang X, Xie GQ, Xi PX, Li ZP, Xu M, Wu YJ, Bai DC, Zeng ZZ. A new rhodamine-based chemosensor for $\mathrm{Cu}^{2+}$ and the study of its behavior in living cells. Dalton Trans, 2010, 39: 7894-7896 and references cited therein

17 Yang XF, Guo XQ, Zhao YB. Development of a novel rhodamine-type fluorescent probe to determine peroxynitrite. Talanta, 2002, 57: 883-890

18 Yin DD, Ren Y, Zhai JF, Qiu L, Shen YQ. Synthesis of a novel organic nonlinear optical molecule MC-FTC. Ниахие Хиеbао, 2004, 62: $518-522$

19 WHO. WHO Guidelines values for chemicals that are of health significance in drinking water. Guidelines for drinking water quality, 3rd ed, Geneva, 2008

20 EU. Council Directive 98/83/EC on the quality of water intended for human consumption, Official Journal of the European Communities, 1998, L330/32-L330/54

21 National Water Quality Management Strategy. Australian Drinking Water Guidelines 6, 2004 